\title{
CLINICAL EFFECT OF DENTAL ADHESIVE ON MARGINAL INTEGRITY IN CLASS I AND CLASS II RESIN-COMPOSITE RESTORATIONS
}

\author{
Neshka A. Manchorova-Veleva ${ }^{1 *}$, Stoyan B. Vladimirov ${ }^{1}$, Donka A. Keskinova ${ }^{2}$ \\ ${ }^{1}$ Department of Operative Dentistry and Endodontics, Faculty of Dental Medicine, Medical University, Plovdiv, \\ ${ }^{2}$ Department of Applied and Institutional Sociology, Faculty of Philosophy and History, Paisii Hilendarski \\ University, Plovdiv, Bulgaria
}

\section{КЛИНИЧЕСКОЕ ЗНАЧЕНИЕ СТОМАТОЛОГИЧЕСКИХ АДГЕЗИВОВ ДЛЯ МАРГИ- НАЛЬНОЙ ИНТЕГРАЦИИ КОМПОЗИТНЫХ ОБТУРАЦИЙ І И ІІ КЛАССА}

\author{
Нешка А. Манчорова-Велева ${ }^{1 *}$, Стоян Б. Владимиров ${ }^{1}$, Донка А. Кескинова ${ }^{2}$ \\ ${ }^{1}$ Кафедра оперативного зуболечения и эндодонтии, Факультет стоматологии, Медииинский \\ университет, Пловдив; ${ }^{2}$ Кафедра прикладной и институциональной социологии, Философско- \\ исторический факультет, Пловдивский университет „Паисий Хилендарски“, Пловдив, Болгария
}

\begin{abstract}
BACKGRound: Dental adhesives are believed to influence marginal adaptation and marginal discoloration when used under posterior resin-based composite restorations. Studies on the latest adhesive systems reveal that the group of the three-step etch-and-rinse adhesive (3-E\&RA) and the one-step self-etch adhesive (1-SEA) have entirely different bonding mechanisms, as well as different bond strength and resistance to chemical, thermal and mechanical factors. STUdy obJEctives: A hypothesis that a 1-SEA would result in greater enamel marginal discoloration and poorer marginal adaptation than a 3-E\&RA was tested. MATERIAL AND METHODS: One hundred restorations were placed with a 1-SEA and 100 restorations with a 3-E\&RA. Teeth were restored with Filtek Supreme nanofilled resin-composite and were evaluated for marginal adaptation and marginal discoloration at baseline, and 6 months, 12 months, and 36 months postoperatively. RESULTs: The statistical analysis revealed significant differences in marginal integrity between test groups. The 1-SEA resulted in greater enamel marginal discoloration and poorer marginal adaptation than the 3-E\&RA at any recall time. ConcLusions: Marginal adaptation and marginal discoloration depend on the type of dentin adhesive used. The restorations with Filtek Supreme and Scotchbond MP are better than the restorations with Adper Prompt L-Pop with regard to the marginal adaptation and marginal discoloration at 6-, 12- and 36-month evaluations.
\end{abstract}

Key words: nanofilled resin-composite posterior restorations, one-step adhesive, three-step adhesive, marginal adaptation, marginal discoloration, clinical evaluation

Folia Medica 2015;57(3\&4):250-256

Copyright (C) 2015 Medical University, Plovdiv

\section{РЕЗЮМЕ}

Введениє: В научно-исследовательских и клинических кругах среди врачей-стоматологов существует мнение, что стоматологические адгезивы оказывают влияние на маргинальную адаптацию и цвет на границах композитных обтураций. Исследования стоматологических адгезивов последних поколений показывают, что одношаговые и трёхшаговые бондинг системы отличаются радикальным образом по механизму связывания, силе связывания и деградации в отношении химических, термических и механических факторов. Цель: Целью настоящей статьи является исследование клинического воздействия одношаговой адгезивной системы и трёхшагового бондинг агента на маргинальную интеграцию при композитных обтурациях жевательных зубов. Проверяется гипотеза: приводит ли употребление одношагового самопротравливающего адгезива Adper Prompt L-Pop к ухудшению маргинальных показателей композитных обтураций I и II класса по сравнению с трёхшаговым агентом Scotchbond MultiPurpose. МАтериАл и методы: Проведено 200 обтураций из нанофильного композита Filtek Supreme. B 100 из них использовался одношаговый самопротравливающий адгезив Adper Prompt L-Pop , а в остальных 100 обтурациях использовался трёхшаговый агент Scotchbond MultiPurpose. Bce обтурации были оценены в отношении маргинальной адаптации и цвета на границах восстановления до лечения и по истечении 6, 12 и 36 месяцев после обтурации. Результаты: Анализ данных показывает наличие статистически значимой разницы между исследованными группами. Обтурации с применением одношагового адгезива отличаются ухудшением цвета на границе эмали и нарушенной маргинальной адаптацией по сравнению с группой трёхшагового бонда на каждом этапе клинической оценки. ЗАключениЕ: Маргинальная 
адаптация и маргинальная окраска зависят от применяемого стоматологического адгезива. Обтурации из Filtek Supreme и трёхшагового адгезива Scotchbond MP превосходят восстановление с применением одношагового бонда Adper Prompt L-Pop в отношении маргинальной интеграции при клинической оценке на 6-ой, 12-ый и 36-ой месяцы.

Ключевые слова: нанофильные композитные обтурации, трёхшаговый адгезив, одношаговый адгезив, маргинальная адаптация, маргинальная окраска, клиническое исследование

Folia Medica 2015;57(3\&4):250-256

(C) 2015 Все права защищены. Медицинский университет, Пловдив

\section{INTRODUCTION}

Studies on the latest adhesive systems show that the group of the 3-E\&RA and 1-SEA have entirely different bonding mechanisms as well as different bond strength and resistance to chemical, thermal and mechanical factors.

Scotchbond Multi Purpose is a three-step, ethanol-water-based adhesive system comprising phosphoric acid etchant, hydrophilic primer monomer and $\mathrm{pH}$-neutral solvent-free hydrophobic adhesive. Considered "gold standard" for efficient adhesion", the 3-E\&RA have overcome the shortcomings of the bonding systems which combine the second and third step of priming and bonding from the same group - the 2-E\&RA. The latter systems have been found to exhibit incomplete evaporation of their solvents that become incorporated in the form of residual water within the collagen fibrils of dentin. The hybrid layer is thick at the expense of the solvent component (water), the bond strength being poor due to the hydrophilicity of the interdiffusion zone and its hydrolytic instability. ${ }^{1}$

Scotchbond MP combines the application of a solvent-free bonding agent in the third step with formation of a hybrid zone thick enough to act like a "stress transformation layer". ${ }^{2}$

A major disadvantage pointed out with this group of adhesives is the hydrolytic instability of the components of the hybrid layer - monomers of the adhesive and collagen fibrils. ${ }^{1,3}$

Adper Prompt L-Pop is a one-step self-etch adhesive, belonging to the group of "strong" systems. It owes its demineralization ability to the action of water-soluble methacrylated phosphoric acid-HEMA esters capable of dissolving the enamel and dentin surface. During the etching process, the $\mathrm{pH}$ of the phosphorus esters increases and causes a self-limiting effect of the demineralization process. The precipitates produced in the process become incorporated in the hybrid layer or evaporate when dried with a gentle airflow. ${ }^{4}$ The monomers effectuating the etching are also responsible for the hybridization. The width of the demineraliza- tion zone corresponds to the monomer penetration depth. Adper Prompt L-Pop forms a hybrid layer that is very fine, barely visible, and heterogeneous. ${ }^{2}$ This is probably due to oxygen inhibition of the polymerization of the monomers in the adhesive because of the thin smear layer and incomplete polymerization. $^{5}$

The limitations of the 1-SEA manifest themselves in several directions: hydrophilicity and instability in relation to diffusion processes (effect of the semi-permeable membrane); high solvent concentration (inadequate width of the hybrid zone and gaps formed by residual solvent); phase separation caused by a change in the monomer/ water ratio during solvent evaporation; interaction between the acidic components of the adhesive and the composite material initiator (weaker bond between them)..$^{1,2}$

It was this polarity in the properties of the 3-E\&RA and 1-SEA systems that provoked our interest in conducting a longitudinal clinical study on class I and class II nanofilled composite restorations with the Scotchbond Multi Purpose three-step system and the Adper Prompt L-Pop (3M ESPE) single-component adhesive.

\section{STUDY OBJECTIVE}

The hypothesis tested in our clinical study was that a 1-SEA would result in greater enamel marginal discoloration and poorer marginal adaptation than a 3-E\&RA.

\section{PATIENTS AND METHODS}

\section{SELECTION CRITERIA}

The clinical study included 89 patients (43 males и 46 females, aged 20 to 35 years), who received a total of 200 restorations. Before participating in the study, patients signed a consent form. The consent form and research protocol were reviewed and approved by an institutional review board (Ethic Committee of Medical University - Plovdiv).

All participants required Class I and Class II restorations in molars and premolars, either 
for replacement of an existing restoration or for treatment of primary carious lesions. All patients demonstrated good oral hygiene and dental health status, except for ongoing restorative procedures in unrelated and unopposed quadrants. Box enumerates specific exclusion criteria. The teeth to be restored had a normal occlusal relationship with natural dentition and opposing and adjacent tooth contact.
The average facio-lingual width of each preparation was greater than or equal to one-third of the distance between the cusp tips. Further details on the patients and the teeth are given in Table 1.

\section{Restorative PROCEDURE}

Preoperative radiographs of the teeth to be restored were obtained. Operative procedures were performed

Table 1. Details of patients and restorations

\begin{tabular}{llcc}
\hline \multicolumn{1}{c}{ Lesion or patient characteristic } & $\begin{array}{c}\text { Prompt } \\
\text { LP }\end{array}$ & $\begin{array}{c}\text { Scotchbond } \\
\text { MP }\end{array}$ \\
\hline \multirow{2}{*}{ Design of preparations } & Conventional & 44 & 42 \\
& Minimal invasive & 56 & 58 \\
\hline \multirow{2}{*}{ Number of restorations on } & Males & 37 & 36 \\
& Females & 63 & 64 \\
\hline \multirow{3}{*}{ Tooth location } & Maxillary & 49 & 41 \\
& Mandibular & 51 & 59 \\
\multirow{2}{*}{ Cavity classification } & Premolar & 34 & 35 \\
& Molar & 66 & 65 \\
\hline \multirow{2}{*}{ Cavity depth } & Class I & 36 & 37 \\
& Class II & 64 & 63 \\
\hline \multirow{3}{*}{ Cavity location } & Caries media & 33 & 34 \\
& Caries profunda & 67 & 66 \\
\hline & Occlusal & 37 & 38 \\
& Mesio-occlusal & 25 & 24 \\
& Disto-occlusal & 30 & 28 \\
& Mesio-occluso-distal & 8 & 10 \\
\hline
\end{tabular}

\section{Box. Patient exclusion criteria}

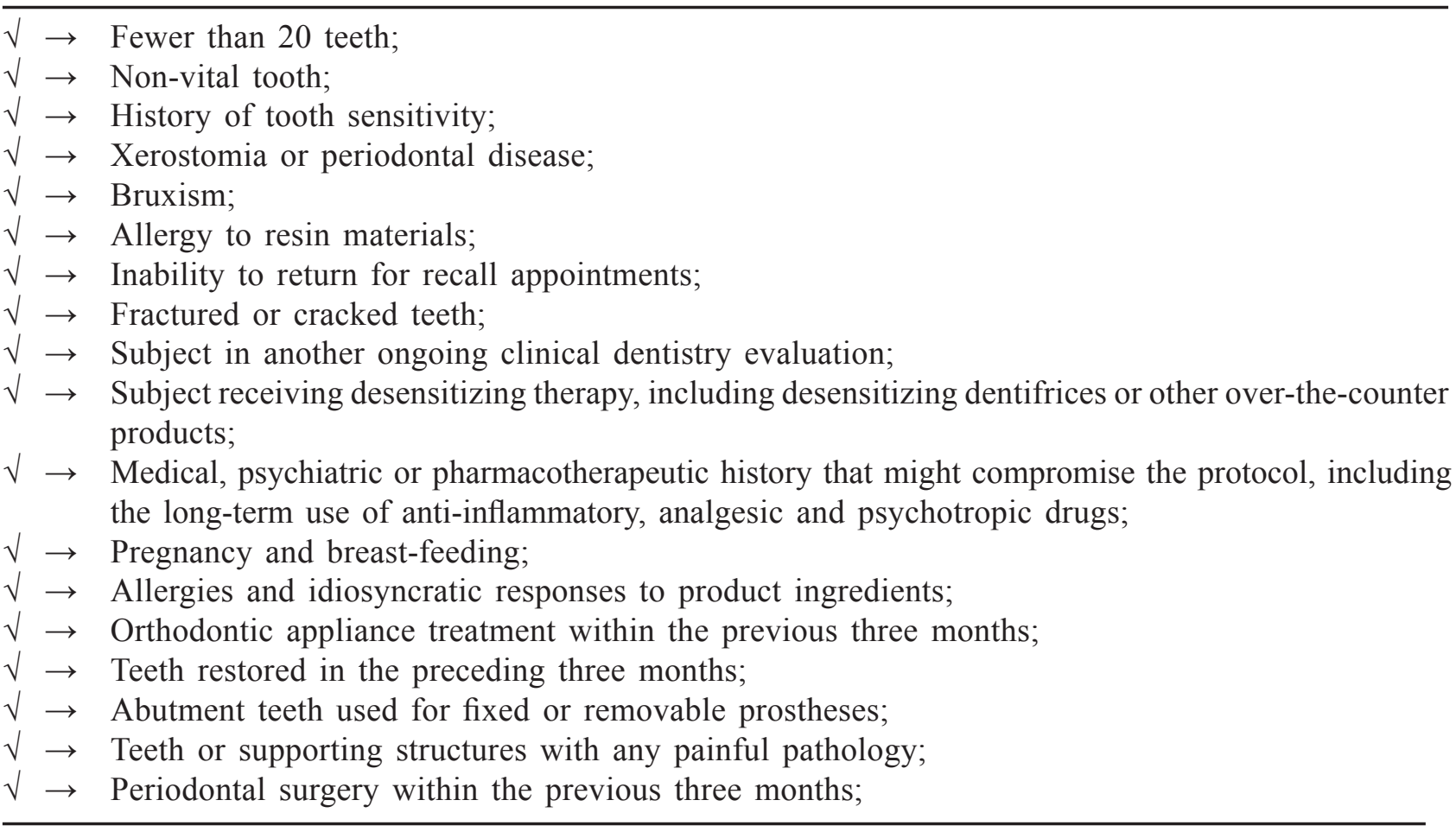


without local anesthesia. Operating sites were isolated with cotton rolls and aspiration. Cavity preparation for adhesive restoration was performed using rotary tools with water/air cooling. Cavo-surface angles of all restorations were entirely within enamel, without any intentional bevel. An appropriate matrix (Super Mat and Super Cap, KerrHawe, Switzerland) and wood wedges (Hawe Sycamore Interdental wedges, KerrHawe, Switzerland) to the cervical margins of Class II restorations were applied. All lesions were prepared, restored and finished by one experienced (NM) operator, who was familiar with adhesive dentistry and who followed the standard procedures and manufacturer's recommendation. The order of placement and selection of material to be placed were randomly allocated for each patient (Box. Patient exclusion criteria).

ApPLICATION OF PRIMER AND ADHESIVE

The 1-SEA system tested was Adper Prompt L-Pop (3M ESPE, St. Paul, MN, USA ) and the 3-E\&RA system was Scotchbond MultiPurpose (3M ESPE, St. Paul, MN, USA). Both adhesives were combined with the nanofilled resin-composite Filtek Supreme
(3M ESPE, St. Paul, MN, USA). To minimize the possible effects of patient-related factors, no more than three restorations per patient were allowed for each adhesive system. The adhesives were used in accordance with the manufacturer's instructions (Table 2). The resin-composite was applied in 2-4 increments and light-cured for $40 \mathrm{sec} /$ increment (Optilux, USA, $600 \mathrm{~mW} / \mathrm{cm}^{2}$ ). The restorations were finished directly under water spray cooling with flame diamond burs (Komet, № 859 EF.314.014) and, finally, polished with Soft-Lex disc system (3M ESPE, St. Paul, MN, USA).

\section{Clinical eVAluation CRITERia}

Evaluation of marginal adaptation and marginal discoloration.

The restorations were examined at baseline and after 6, 12 and 36 months. All restorations were evaluated according to USPHS criteria. The variables evaluated were marginal adaptation and marginal discoloration. Marginal discoloration was evaluated by visual inspection with a mirror according to this scale: A - no discoloration anywhere along the margin; B - superficial staining (removable,

Table 2. Adhesive systems and resin composite: composition and instructions for use

\begin{tabular}{|c|c|c|c|}
\hline $\begin{array}{l}\text { Adhesive/ } \\
\text { resin-com- } \\
\text { posite }\end{array}$ & $\begin{array}{c}\text { Classifica- } \\
\text { tion }\end{array}$ & Composition & Instructions for use \\
\hline
\end{tabular}

Liquid 1: methacrylated phosphoric Adper Prompt One-step, esters, Bis-GMA, initiators based on L-Pop self-etch adhesive camphoroquinone, stabilizers. Liquid 2: water, HEMA, polyalkenoic acid, co-polymer, stabilizers. a - Mixed liquid A and liquid B;

b - One coat of mixture application (15s);

c - air-dry (10s);

$\mathrm{d}-$ Second coat of mixture application (15s);

e - air-dry (10s);

$\mathrm{f}$ - Light-cure $\left(10 \mathrm{sec} .-600 \mathrm{~mW} / \mathrm{cm}^{2}\right)$

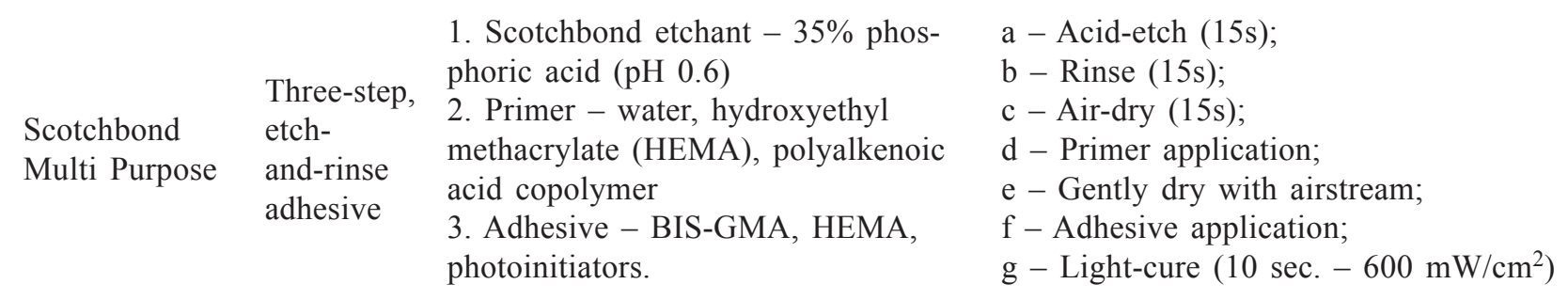

\begin{tabular}{|c|c|c|}
\hline \multirow{6}{*}{ Filtek Supreme } & \multirow{6}{*}{$\begin{array}{l}\text { Nanofilled } \\
\text { resin-com- } \\
\text { posite. }\end{array}$} & \\
\hline & & \\
\hline & & $\begin{array}{l}\text { Filler: } 59.5 \text { vol. } \%(78.5 \text { wt. } \%) \text { of } \\
\text { combination of nanomeric particles }\end{array}$ \\
\hline & & and nanoclusters with primary par- \\
\hline & & Resin: Bis- GMA, UDMA, TEGDMA \\
\hline & & $\begin{array}{l}\text { Additional contents: stabilizers, cata- } \\
\text { lysts and pigments }\end{array}$ \\
\hline
\end{tabular}

a - Increment placement $(<1.5 \mathrm{~mm})$;

b - Light-curing $\left(30 \mathrm{~s}-600 \mathrm{~mW} / \mathrm{cm}^{2}\right)$ 
usually localized); C - deep staining. Marginal adaptation was evaluated by visual inspection with an explorer and mirror, if needed, according to this scale: A - Undetectable crevice along the margin; B - Detectable V-shaped defect in enamel only; C - Detectable V-shaped defect in DEJ.

Two clinicians trained in the technique and not involved with the treatment procedures evaluated each restoration. When there was disagreement during an evaluation, the ultimate decision was made by consensus of the examiners, who were calibrated before the study by a joint examination of 20 composite restorations each. Intraoral color photographs were taken at baseline and each recall appointment. Clinical photographs consisted of digital images taken at an original magnification of $\times 1.0$ or $\times 1.5$.

\section{Statistical anAlysis}

Descriptive statistics were used to describe the frequency distributions (Proportion and Standard Error) of the evaluated criteria. The Fisher's exact test was used to compare durability of adhesive systems in each evaluated period and McNemar's test was chosen to estimate marginal integrity of restorations between evaluated periods. $\alpha$ was set at 0.05 .

\section{RESULTS}

Table 3 shows the longitudinal comparative clinical characteristics of the restorations that received maximum scores (Alfa).

Statistically significant changes in the marginal discoloration of the restorations were observed in the group of the 1-SEA as early as 6 months (p $=0.00)$ as compared to the baseline score. The marginal discoloration of the restorations at the 12-month follow-up was statistically insignificant, compared to the 6-month score $(\mathrm{p}=0.05)$. After a three-year function, the restorations performed with Adper Prompt L-Pop manifested significantly worse marginal discoloration in comparison with that at 12 months $(p=0.00)$.

An insignificant change in the marginal adaptation was established in the restorations made with the 1-SEA after 6 months, compared to the initial score $(\mathrm{p}=0.13)$. A progressive deterioration in this indicator was observed at 12 months $(\mathrm{p}=$ 0.00 ). There was statistically significant difference between the marginal adaptation after a three-year function of the restorations in comparison with the score of the previous follow-up period $(\mathrm{p}=0.00)$.

In the group of restorations where the 3-E\&RA system was used there was a significant change in the marginal discoloration of the restorations only after 36 months, compared to the initial score (p $=0.03)$. In the intra-group comparison, a more

Table 3. Comparative longitudinal clinical characterization of restorations with maximum scores (Alfa)

\begin{tabular}{|c|c|c|c|c|c|c|c|c|c|}
\hline \multirow{2}{*}{ Criteria } & \multirow{2}{*}{$\begin{array}{l}\text { Observation } \\
\text { period }\end{array}$} & \multicolumn{3}{|c|}{$\begin{array}{l}\text { Adper Prompt } \\
\text { L-Pop }\end{array}$} & \multicolumn{3}{|c|}{$\begin{array}{l}\text { Adper Scotchbond } \\
\text { Multi Purpose }\end{array}$} & \multicolumn{2}{|c|}{ Significance } \\
\hline & & $\mathbf{n} *$ & $\mathbf{n}^{\mathbf{A}}$ & $\begin{array}{l}\text { Proportion } \\
\text { (SE) }\end{array}$ & $\mathbf{n} *$ & $\mathbf{n}^{\mathbf{A}}$ & $\begin{array}{l}\text { Proportion } \\
\text { (SE) }\end{array}$ & Chi-Square & $\begin{array}{c}\text { Fisher's } \\
\text { Exact Test }\end{array}$ \\
\hline \multirow{4}{*}{$\begin{array}{l}\text { Marginal } \\
\text { adaptation }\end{array}$} & Initial scores & 100 & 100 & 100 & 100 & 100 & 100 & - & - \\
\hline & After 6 months & 92 & 88 & $\begin{array}{l}95.6 \\
(2.14) \\
\end{array}$ & 90 & 90 & 100 & $\mathrm{p}=0.05$ & $\mathrm{p}=0.12$ \\
\hline & After 12 months & 87 & 67 & $\begin{array}{c}77.0 \\
(4.51) \\
\end{array}$ & 82 & 79 & $\begin{array}{l}96.3 \\
(2.08) \\
\end{array}$ & $\mathrm{p}=0.00$ & $\mathrm{p}=0.00$ \\
\hline & After 36 months & 70 & 52 & $\begin{array}{c}74.3 \\
(5.22) \\
\end{array}$ & 67 & 60 & $\begin{array}{l}89.5 \\
(3.74) \\
\end{array}$ & $\mathrm{p}=0.02$ & $\mathrm{p}=0.03$ \\
\hline \multirow{4}{*}{$\begin{array}{l}\text { Marginal } \\
\text { discolo- } \\
\text { ration }\end{array}$} & Initial scores & 100 & 100 & 100 & 100 & 100 & 100 & - & - \\
\hline & After 6 months & 92 & 74 & $\begin{array}{c}80.4 \\
(4.14) \\
\end{array}$ & 90 & 87 & $\begin{array}{c}96.7 \\
(1.88) \\
\end{array}$ & $\mathrm{p}=0.00$ & $\mathrm{p}=0.00$ \\
\hline & After 12 months & 87 & 72 & $\begin{array}{c}82.7 \\
(4.05)\end{array}$ & 82 & 78 & $\begin{array}{l}95.1 \\
(2.38)\end{array}$ & $\mathrm{p}=0.01$ & $\mathrm{p}=0.01$ \\
\hline & After 36 months & 70 & 45 & $\begin{array}{c}64.3 \\
(5.73)\end{array}$ & 67 & 61 & $\begin{array}{c}91.0 \\
(3.50)\end{array}$ & $\mathrm{p}=0.00$ & $\mathrm{p}=0.00$ \\
\hline
\end{tabular}

$\mathrm{n}^{*}$ - total number of evaluated restorations; $\mathrm{n}^{\mathrm{A}}$ - number of restorations assigned maximum score A (Alfa) 
stable colour was observed along the margins of the restorations performed with a separate etching step for all studied periods $(\mathrm{p}=0.25 ; \mathrm{p}=0.13$, respectively).

The evaluation of the marginal adaptation of the restorations made with Adper Scotchbond Multi Purpose reveals a significant change in this indicator at 36 months, compared to the baseline $(\mathrm{p}=0.02)$. The restorations with a separate etching step are superior to the restorations with a self-etch adhesive with regard to the adaptation at the cavity margins at 6-month, 12-month and 36 -month evaluation $(\mathrm{p}=0.25)$.

\section{DISCUSSION}

The most dynamic change was recorded in the evaluation of the marginal discoloration and marginal adaptation that manifested themselves after only six months of functioning. They can be accounted for by the degradation of the adhesive bond that occurs in the first months after restoration.

The adhesive bond degradation in the one-step self-etch systems could be caused by the specific etching mechanism, hybridization and the morphology of the interdiffusion zone.

Adper Prompt L-Pop is a single-component adhesive belonging to the group of "aggressive" self-etch systems. ${ }^{1,2}$ Enamel and dentin etching occurs under the demineralizing action of the monomers in the adhesive with $\mathrm{pH}<1$. In this way the demineralization pattern of hydroxylapatite comes close to the way of action of phosphoric acid in the systems with separate etching. ${ }^{5,6}$ Some authors do not support this view as they have found a poor etching ability mainly towards the enamel. ${ }^{4}$ The present study recorded a change in the marginal discoloration only in the enamel of all evaluated restorations, which is a regular finding in other clinical studies on Prompt L-Pop. ${ }^{7}$

A disadvantage with this group of adhesive systems ("strong" 1-SEA) is the disability of the monomers to penetrate to the same depth as the depth of demineralization. Thus, a complete threedimensional infiltration of the collagen fibrils and apatite, partially dissolved and transformed by the adhesive monomers, is not possible. Bonds of different nature have been discussed: in addition to the micromechanical bond between the adhesive and dentin, there could also be chemical bonding between the phosphorus esters and the $\mathrm{Ca}$ ions in apatite $^{2,4,8,9}$, which should be a prerequisite for good clinical results.

A characteristic property of the one-step sys- tems is their hydrophilicity. On the one hand, the tolerance of the monomers to moisture in their structure promotes adhesion with dentin in its natural environment, without any need for changing its state of hydration. The monomers possess the same polarity, solubility and surface energy as dentin. Thus, the laws of polymer chemistry for achieving an adhesive bond are satisfied. On the other hand, the hydrophilic nature of the adhesive leads to hydrolytic instability, entailing a number of adverse results: dissolution of the incompletely polymerized hydrophilic monomers in the hybrid layer, proven in vivo ${ }^{1,2}$; reduction of the bonds between the polymer chains, a process known as "plasticization"1,2; enzyme degradation - esterases, products of microorganisms in vivo, catalysis of the degradation of the unpolymerized components from the plastic matrix ${ }^{4}$. Matrix-metalloproteinases produced by the oral flora can hydrolyze adhesiveunincorporated collagen fibrils. ${ }^{10}$ "Strong" 1-SEA also activate the production of matrix-metalloproteinases from the odontoblasts by their low $\mathrm{pH}$ (acidic activation) $)^{3,10}$, where the proteolytic stimulation by the adhesives correlates with their acidity ${ }^{12}$. The high acidity and hydrophilicity of the monomers of the 1-SEA results in inadequate hybridization. ${ }^{2,4}$ The droplets observed in the hybrid layer of the HEMA-rich self-etch adhesives (such as Adper Prompt L-Pop) are caused by water absorption from dentin through osmosis. This can result in a fragile zone and in easy interfacial fracture. ${ }^{13}$ The facilitated movement of ions through the hybrid layer is known as nanoleakage. They are regarded as semi-permeable membranes for diffusion processes. ${ }^{1,2}$ Bond degradation in the self-etch adhesives occurs within relatively short time ${ }^{2,3}$, which is confirmed by the results of this study for statistically significant deterioration of marginal discoloration after 6 months $(\mathrm{p}<0.05, \mathrm{u}=4.73)$.

The present study found that the marginal adaptation was similar to the results obtained by Bittencourt et al., 2005 ${ }^{14}$, who studied Adper Prompt L-Pop, but in class $\mathrm{V}$ cavities.

In the evaluation of the restorations with Scotchbond MP, the present results show advantages in relation to the marginal discoloration and adaptation along the cavity margins, as compared to the restorations with Adper Prompt L-Pop. These observations are similar to the results by other authors. ${ }^{1-4}$

The good clinical performance of the restorations with Scotchbond MP can be explained by the different adhesion strategy in this group of 
systems. The 3-E\&RA combine the effect of the demineralization properties of phosphoric acid, the requirement for similarity between the hydrophilic primer and the moist dentin, and the hydrolytic stability of the bond secured by a $\mathrm{pH}$-neutral hydrophobic adhesive. The stability of the bond is guaranteed by the complete incorporation of the collagen fibrils in the hydrophobic monomers of the adhesive, placed in a separate step. In this sense, the three-step ethanol-water-based adhesives are regarded as a "gold standard" for effective adhesion, especially in wide cavity preparation with margins in dentin. ${ }^{1,3}$

The statistically significant difference in the marginal adaptation and marginal discoloration established in the present study after 36 months of function, compared to the initial score, could result from hydrolytic degradation of the bond. Perhaps this is caused by the high molecular weight of the copolymer of the polyalkenoic acid, incorporated in the hybrid layer. ${ }^{1,3}$ There is a description of phase separation of the copolymer, spreading like gel on the surface of the collagen mesh. ${ }^{13}$ That could lead to stereometric obstacles to the adequate hybridization and infiltration only of molecules with molecular weight like HEMA. They polymerize to linear poly(HEMA) chains with included residual aqueous component. Some of the monomers in the adhesive could be unstable towards hydrolysis ${ }^{15}$ or open dentin collagen fibrils, unincorporated with resin ${ }^{10}$. In long-term studies in vitro (four years) the adhesive bond with Scotchbond MP is subjected to degradation during thermocycling and storage in an aqueous medium. ${ }^{1,3}$

\section{CONCLUSIONS}

The restorations with Filtek Supreme and Scotchbond MP excel the restorations with Adper Prompt L-Pop with regard to the marginal adaptation and marginal discoloration during 6-, 12- and 36-month evaluations.

\section{ACKNOWLEDGMENTS}

The authors would like to thank the company of $3 \mathrm{M}$ ESPE, St. Paul, MN, USA for their generous material support.

\section{REFERENCES}

1. De Munk J, Van Landuyt K, Peumans M, Poitevin A, Lambrechts P, Braem M, Van Meerbeek B. A critical review of the durability of adhesion to tooth tissue: methods and results. J Dent Res 2005;84(2):118-32.

2. Van Meerbeek B, Peumans M, Poitevin A, et al. Relationship between bond-strength tests and clinical outcomes. Dent Mat 2010;26:e100-e21.

3. De Munk J, Van den Steen P, Mine A, Van Landuyt K, Poitevin A, Opdenakker G, Van Meerbeek B. Inhibition of enzymatic degradation of adhesivedentin interface. J Dent Res 2009;88:1101-6.

4. Perdigao J. Dentin bonding - variables related to the clinical situation and the substrate treatment. Dent Mater 2010;26:e24-e37.

5. Demarco FF, Correa MB, Cenci MS, et al. Longevity of posterior composite restorations: Not only a matter of materials. Dent Mat 2012;28:87-101.

6. Rodolpho PR, Donassollo TA, Cenci MS, et al. 22year clinical evaluation of the performance of two posterior composites with different filler characteristics. Dent Mat 2011;27:955-63.

7. Brackett WW, Covey DA, St-Germain HA Jr. Oneyear clinical performance of self-etching adhesive in class $\mathrm{V}$ resin composites cured by two methods. Oper Dent 2002;27:218-22.

8. Yazici AR, Ustunkol I, Ozgunaltay G, Dayangac B. Three-year Clinical Evaluation of Different Restorative Resins in Class I Restorations. Operative Dentistry 2013: (article in press).

9. Becka F, et al. One-year evaluation of two hybrid composites placed in a randomized-controlled clinical trial. Dent Mat 2014:(article in press).

10.Pashley DH, Tay FR, Yiu C, Hashimoto M, Breschi L, Carvalho RM, et al. Collagen degradation by host-derived enzymes during aging. J Dent Res 2004;83(3):216-21.

11. Lehman N, Debret R, Romeas A, Magloire H, Degrange $\mathrm{M}$, Bleicher $\mathrm{P}$, et al. Self-etching increases matrix metalloproteinase expression in the dentinpulp complex. J Dent Res 2009;88:77-82.

12. Nishitani Y, Yoshigama M, Wadaonkar B, breshi L, Mannello F, Mazzoni A, et al. Activation of gelanolitic/collagenolitic activity in dentin by self-etching adhesives. Eur J Oral Sci 2006;114:160-6.

13. Van Landuyt K, Snauwaert J, De Munk J, Continho E, Poitevin A, Yoshida Y, et al. Origin of interfacial droplets with one-step adhesives. J Dent Res 2007;86:739-44.

14. Bittencourt DD, Ezecelevski IG, Reis A, Van Dijken JW, Loguercio AD. An 18-months evaluation of selfetch and etch \& rinse adhesive in non-carious cervical lesions Acta Odontol Scand 2005; 63(3):173-8.

15. Thomsen KB, Peutzfeldt A. Resin composite: strength of the bond to dentin versus mechanical properties. Clin Oral Invest 2007;11(1):45-9. 